Please acknowledge as follows: Elke Krahmann, Private Military and Security Companies, Territoriality and the Transformation of Western Security Governance, in: Stefano Guzzini and Iver B. Neuman eds., The Diffusion of Power in Global Governance. International Political Economy meets Foucault, October 2012, Basingstoke: Palgrave Macmillan, pp.38-70, reproduced with permission of Palgrave Macmillan.

This extract is taken from the author's original manuscript and has not been edited. The definitive, published, version of record is available here: http://www.palgrave.com/page/detail/the-diffusion-of-power-in-globalgovernance-stefano-guzzini/?K=9780230302778

\title{
Private Military and Security Companies, Territoriality and the Transformation of Western Security Governance
}

\author{
Elke Krahmann
}

\section{Introduction}

The field of security governance holds a special place within the context of the debate over the diffusion of power from state to non-state actors, from national to international authorities and from governments to markets in Western democracies. Not only has the provision of the 'public good' security been considered one of the main functions of government, but also has it played a major role in justifying the centralization of power and authority within and by the nation-state (Krahmann, 2010; Leander 2006). The contemporary proliferation of private military and security companies, i.e. companies that sell armed and non-armed security services to public and private customers, poses a particular challenge to state-centric notions of national and global governance. Of course, commercial security providers are not new. Businesses have always played a role in national and international security, whether as mercenaries, armaments producers or logistics suppliers in major conflicts. The increasingly global scale of the private military and security industry, its functional expansion into areas previously considered to be inherently governmental' as well as their growing use by private individuals and business customers, however, suggest a significant transformation in security governance since the "golden age" of the Western nation-state in the mid-twentieth century (Leibfried et al., 2008; also Hogan, 2000; Edgerton, 2006). Notably, 80 percent of their customers are individuals and corporations, suggesting significant private power over the provision of security.

This chapter seeks to examine the consequences of the diffusion of security governance functions among military and security companies in Europe and North America. It focuses specifically on two problematiques identified in the introduction to this volume. The first is the changing scope of security governance because commercial security provision shifts the focus from the territory of the nation-state to subnational and international levels, and decision-making power from state to non-state actors. The second problematique is the implications of this diffusion for the norms and values underlying security governance. The chapter argues that it is in particular the distinct territorialities of commercial security provision that contribute to challenging the traditional state-centric foundations of security governance in Western democracies and promote the re-allocation of basic values. 
To analyse the consequences of the growing role of military and security contractors, this chapter is structured into four parts. The first part outlines how the concept of territoriality in the ideal of the sovereign nation-state has provided the foundation for the mechanisms and values that defined Western security governance during the mid-twentieth century. The second part analyses empirically how commercial security providers are in the process of changing the territorial foundations of national and international security with a particular focus on Europe and North America. As a consequence, the chapter contends in the third part, the commercialization of security affects four values which have been central to the understanding of Western security governance in the past century: (1) the state monopoly on the legitimate use of force, (2) the notion that security relates to communities rather than individuals, (3) the rule of law and (4) the democratic control over the provision of security. The chapter concludes that the diffusion of power to commercial security providers is contributing to transforming the practical and normative foundations of national and global security governance.

\section{Territoriality and the State-Centric Order}

In order to analyse the implications of the commercialization of security, it is first necessary to understand the characteristics of the state-centric political order and the practices and norms which have emerged on its foundations. Territoriality has been one of the central concepts of this order. Territoriality has provided the framework for the notion that government should proceed exclusively within the physical borders of a (nation-)state and that citizens, their rights and obligations are defined by being born or living within these borders. Moreover, the concept of territorial sovereignty has led to the assertion that states must not interfere into the government of other states and that the government outside their territorial boundaries is to be decided only by states which are to be treated as formally equal. In sum, the state-centric order is premised on "exclusive control over territory, non-interference, and equality among states" (Fitzpatrick, 2002, p. 304). As these ideals spread slowly across Europe and North America after the signing of the Treaty of Westphalia in 1648, the territorial state became a central unit of reference for a normative order embodied in national and international practices and law (Zacher, 2001). In practice, of course, the state-centric political order has always had its limitations. According to Stephen D. Krasner (1995/6), the territorial sovereignty of the nation-state has been variously compromised through conventions, contracting, coercion and imposition. Nevertheless, the ideal of a territorial political order based on sovereign nation-states has been strong, reaching its fullest expression among Western democracies during the twentieth century. State-centrism has shaped political practice and its underlying normative order.

With regard to the provision of security, four normative values and practices have been particularly closely linked to the territorial state: the norm against the private use of force, the values of community, the rule of law and the democratic control of security. While the first two concern primarily the provision of security, the second two apply to the public control of the use of armed force. Within the order of territorial states, the norm against private force has taken the shape of the state monopoly on the legitimate use of violence (Weber, 1994, pp. 310-311). This norm, which prohibits the private use of force in all circumstances but immediate self-defence, has two primary aims with regard to security. The first is the elimination of intentional physical violence among the members of a 
territorially circumscribed community. The second is the avoidance of international conflict between individuals from different territorial communities. In both cases, the 'natural right' to employ force is deferred to the state in return for protection against internal and external aggressors.

The second practice and value establishes a link between security and a territorial social community, represented by the ideal of the nation-state. The norm builds on the belief that humans are inherently social beings and that many human needs can only be satisfied collectively. For the provision of security it means that, while individuals can protect themselves through self-defence, the fear of aggression from other human beings would severely limit the fulfilment of many inherently social needs. The territorial nation-state serves to facilitate the fulfilment of these needs through two measures. One is the creation of territorial zones of peace in which citizens can create a social community. The second concerns the collectivization of resources and efforts for the protection of the community against external threats from beyond its territorial borders.

The order based on the territorial state has not only provided the framework for contemporary norms and practices regarding the provision of security, it has also shaped values regarding the control of security governance. Specifically, it has been the foundation of two modern values: the rule of law and democracy. According to Joseph Raz (cited in O'Donnell, 2004, p. 35) the rule of law is defined by several characteristics:

"1. All laws should be prospective, open and clear; 2 . Laws should be relatively stable; 3 . The making of particular laws ... must be guided by open, stable, clear, and general rules; 4 . The independence of the judiciary must be guaranteed; 5 . The principles of natural justice must be observed (i.e., open and fair hearing and absence of bias); 6 . The courts should have review powers ... to ensure conformity with the rule of law; 7 . The courts should be easily accessible; and 8 . The discretion of crime preventing agencies should not be allowed to pervert the law."

Guillermo O'Donnell adds that "truly democratic rule of law ... ensures political rights, civil liberties, and mechanisms of accountability which in turn affirm the political equality of all citizens and constrain the potential abuses of state power" (O'Donnell, 2004, p. 32).

Democracy, in turn, is defined as the self-government of the citizens, coming from the Greek words 'demos' for people or citizens, and 'kratos' for rule. The term demos also referred to the 'village' where males enrolled for participation in ancient Athenian self-rule, giving an example of a territorial notion of democracy well before modern times (Blackwell, 2003). Territoriality plays a central role for both, contemporary rule of law and modern democracy. Territoriality not only sets the boundaries for the application of both values, it also ensures through the ideal of the democratic rule of law that the two spheres are identical. Only where all the citizens who are ruled by the law also have the opportunity to participate in defining the law can we speak of democratic self-rule. Moreover, the values of democracy and the rule of law are linked in that the rule of law should safeguard the self-rule of the citizens.

\section{The Territoriality of Commercial Security}

The proliferation of security companies directly and indirectly affects the practices, values and norms of Western security governance by transforming the territorial conditions for its provision. This section outlines the scope of the commercialization of security at two levels 
across Europe and North America: domestic security services and international security governance.

The growth of domestic security services across Europe and North America since the 1970s has received little public or media attention. Few citizens and politicians are aware of the scale to which security contractors dominate the provision of subnational security today. As table 1 shows the number of security contractors is nearly twice as large as that of public police forces in the United Kingdom (UK), Poland, the United States and Turkey, and two thirds the size of the state police in France and Germany. Moreover, the United States (USA), Poland, Germany, Turkey and Spain permit the carrying of arms by contract security guards. Expressly prohibited is the use of arms only in the UK and France, although the latter grants exceptions for transport security services. About 80 percent of commercial security services are directly sold to private citizens and corporations, effectively competing with the sovereign nation-state as the primary supplier of security within its territorial borders.

Table 1. Domestic Security Providers 2007-2008 (CoESS, 2008; US Bureau of Labor Statistics, 2008)

\begin{tabular}{|l|l|l|l|l|}
\hline Country & Public Police & Security Contractors & $\begin{array}{l}\text { Armed Security } \\
\text { Contractors }\end{array}$ & $\begin{array}{l}\text { Ratio Police/ } \\
\text { Security } \\
\text { Contractors }\end{array}$ \\
\hline United Kingdom & 141,398 & 250,000 & - & 0.6 \\
\hline Poland & 100,000 & 165,000 & No data & 0.6 \\
\hline United States & 861,000 & $1,200,000$ & No data & 0.7 \\
\hline Turkey & 145,000 & 218,660 & 35,263 & 0.7 \\
\hline Germany & 250,000 & 177,000 & 10,000 & 1.4 \\
\hline France & 250,000 & 159,000 & - & 1.6 \\
\hline Spain & 223,000 & 92,000 & 20,000 & 2.4 \\
\hline
\end{tabular}

Security companies also directly affect the territorial provision of security. The rise of commercially policed spaces in Europe and North America illustrates this development. Foremost is the proliferation of mass private property, including gated communities, shopping malls, business parks and amusement districts (Shearing and Stenning, 1983; Blakely and Snyder, 1997; Wilson-Doenges, 2000; Monahan, 2006; Atkinson and Blandy, 2005). According to the Community Association Institute (2009), nearly 60 million US citizens, i.e. 20 percent of the total population, lived in self-governed residences in 2008, compared to 45 million in 2000. More than 17 million housing units in the USA are physically protected from their neighbourhood through gates, walls, fences and commercial security services (US Census Bureau, 2008, p. 66). Also in the UK, the number of gated communities has been increasing. In 2004, Atkinson and Flint counted "around 1,000 gated communities in England", many of which were located in the wealthy Southeast (Atkinson and Flint, 2004, p. 879). Smaller increases in commercially secured residences have been noted in France, Turkey and Spain (Glasze, 2005, p. 222).

Despite these numbers, the pervasiveness of 'private' security territories is often underestimated because gated communities are only one example of mass private 
properties. Beyond private housing and residential areas, also corporations and public institutions such as hospitals and universities are increasingly hiring commercial security services to protect their premises. The commercial patrolling of shopping malls, university precincts, train stations, airports and office buildings has become so commonplace in Western industrialized countries that people hardly take note of it anymore. The scale of commercial security guarding is revealed by statistics from the UK which suggest that the turnover of this service segment has more than quadrupled in the past fifteen years [Figure 1].

Figure 1. British Security Industry Turnover
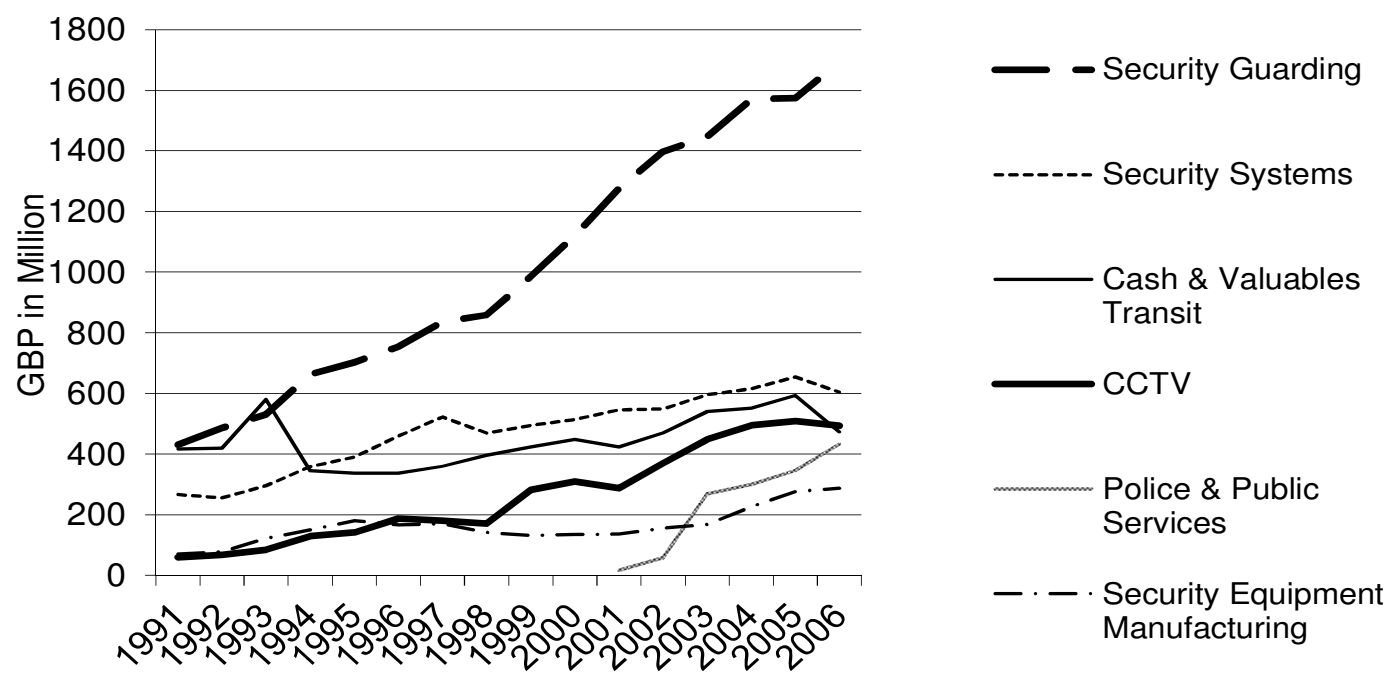

The commercial protection of formerly public spaces has contributed to the current boom of the sector. The most extreme case has been the 'privatization' of inner city districts and public streets in the UK and the USA. In the UK, this has taken two forms. One has been the outsourcing of state responsibility for the policing of streets with a high density of bars and clubs to these establishments. Another has been the private lease of public spaces such as London's Chinatown and 42 acres in Liverpool's city centre by commercial developers (Kingsnorth, 2008). In both areas citizens retain public rights of way, but security is provided jointly by privately employed contract security guards and the public police. 
Table 2. International Security Companies ${ }^{1}$

\begin{tabular}{|l|l|l|}
\hline Company & Subsidiaries, Offices and Operations & Employees \\
\hline $\begin{array}{l}\text { G4S (incl. ArmorGroup, } \\
\text { Wackenhut, Ronco) }\end{array}$ & Subsidiaries in 38 countries; operations in 125 countries & 625,000 \\
\hline Securitas & Subsidiaries or operations in 49 countries & 295,000 \\
\hline CSC (incl. DynCorp) & $\begin{array}{l}\text { Offices in } 35 \text { countries and operations in more than } 90 \\
\text { countries }\end{array}$ & 97,000 \\
\hline L-3 (incl. MPRI, Titan) & Offices in 8 countries & 63,000 \\
\hline Guardsmark & 150 offices worldwide & 17,000 \\
\hline CACl & More than 120 offices in North America and Europe & No data \\
\hline Control Risks & 34 offices worldwide & No data \\
\hline The Risk Advisory Group & $\begin{array}{l}\text { Offices in US, UK, Russia, Saudi Arabia, Dubai and } \\
\text { operations in 100 countries }\end{array}$ & No data \\
\hline Olive Group & 11 offices worldwide and operations in 30 countries & 900 \\
\hline
\end{tabular}

While the majority of security companies work within the territorial boundaries of their headquartered states, a growing number of firms operate internationally. Often they work for states and their agencies, in particular in international interventions. However, increasingly also non-state actors, such as transnational corporations and non-governmental organizations (NGOs) are employing international security companies to protect their operations abroad.

The global territorial expansion of security firms occurs in two main dimensions. Firstly, a growing number of security companies have become transnational corporations through the merger with or acquisition of national security firms and the opening of offices around the globe. Key examples are G4S and Securitas. G4S has subsidiaries in 38 countries, provides security in 125 states and counts a total of 625,000 employees worldwide. Securitas has subsidiaries or operations in 49 countries with a total staff of about 295,000. Securitas has a global market share of 12 percent. Other security companies such as CSC, L-3, Guardsmark and $\mathrm{CACl}$ from the USA and Control Risks, The Risk Advisory Group and Olive from the UK have expanded their operations through regional or national offices in Europe, Asia, the Middle East and Latin America.

Secondly, as illustrated by table 3 , the use of military contractors and commercial security guards has increased massively in international military and humanitarian interventions as well as by transnational corporations operating in regions of conflict or failed states. In 2009, the US military alone employed 155,000 military and security contractors in Iraq, about 25,000-30,000 of whom were armed. In addition, an estimated 48,000 commercial security guards worked for reconstruction firms, international organizations, NGOs and private businesses in Iraq. Also in Afghanistan, international military and security contractors played a major role in the provision of security services with 30,000 US military contractors and about 10,000 privately hired security staff. A comparison with previous interventions illustrates the growth of the commercial security sector. According to US government

\footnotetext{
${ }^{1}$ G4S (2012); Securitas (2012); CSC (2012); L-3 Communications (2011); Guardsmark (2011); CACI (2012); Control Risks (2012a); The Risk Advisory Group (2012); Olive Group (2012).
} 
figures, "the ratio of about one contractor employee for every member of the U.S. armed forces in the Iraq theatre is at least 2.5 times higher than that ratio during any other major U.S. conflict" (CBO, 2008, p. 1).

Table 3. International Interventions

\begin{tabular}{|l|l|l|l|l|}
\hline Country & Soldiers (foreign) & $\begin{array}{l}\text { Military Support } \\
\text { Contractors } \\
\text { (US only) }\end{array}$ & $\begin{array}{l}\text { Security } \\
\text { Contractors }\end{array}$ & $\begin{array}{l}\text { Ratio } \\
\text { Soldiers/Contractors }\end{array}$ \\
\hline Iraq & 152,000 & 155,000 & 48,000 & 0.7 \\
\hline Afghanistan & 53,000 & 30,000 & 10,000 & 1.3 \\
\hline
\end{tabular}

The services sold on the global security market cover "every aspect of security - from corporate operations, commercial risk and foreign investment to counter-terrorism, close protection and support to governments" (Aegis, 2011). In some instances international security companies directly replace or compete with local police and national armed forces. This occurs predominantly in weak or failed states where the latter are unable to maintain public security such as in Angola, Algeria, Nigeria and the Democratic Republic of Congo. State agencies in these countries might even be seen as a cause of insecurity due to "endemic state corruption, personal or corporate blackmail or straight theft" against which international security firms have to protect their international clients (Control Risks, 2012b). However, also in industrialized countries international security firms are supplying armed guards and perimeter protection. According to these firms, international terrorism and organised crime affect international corporations, major banking, financial and manufacturing companies, governments and other multi-national organisations around the world. In addition to armed protection, global security firms offer terrorist damage services, project security management and consultancy, security design and architecture, security audits and reviews, supply chain security, executive protection, event security, sports event security management, technical surveillance countermeasures, whistleblowing services and forensics.

\section{Challenging State-Centric Orders}

The commercialization of security is neither new nor unwanted. In most cases, Western states have accepted, even promoted, the transfer of security functions to commercial contractors. However, the consequences of the changing practices of domestic and international security provision have been little examined and understood by these governments. This section argues that commercial security changes the territoriality of contemporary security governance and, thus, one of the foundations of traditional Western state-centric political and normative orders. The following examines four aspects of this order: the state monopoly on violence, political community, rule of law and democracy. 


\section{State Monopoly on Violence}

One of the most important consequences of the growth of the security industry is the erosion of the monopoly of the territorial state on the legitimate use of violence and with it, the norm against the private application of force in national and international affairs. Although even among Western states this monopoly has never been complete, the proliferation of commercial security guards and protection since the 1970s indicates a marked reversal of the progressive centralization of the control of armed force by Western states over the past three centuries (Thomson, 1994). This reversal also applies to the norm against mercenarism which emerged concurrently with the state monopoly on violence (Percy, 2007; Krahmann, 2012). The theoretical and normative implications include that the state is no longer the sole or even primary legitimate provider of security within its national territory and in international relations (Loader and Walker, 2001, p. 10).

Within national territories in Europe and North America the expansion of the security industry has two major effects on the state monopoly on violence. Firstly, the availability of commercial security services challenges the role and ideal of the state as the supplier of public security (Andreas and Price, 2001, p. 35; Bislev, 2004, p. 282). Secondly, the proliferation of armed security guards reverses the trend towards eliminating the use of physical violence among the peoples living within the territorial borders of a state. Both aspects are inherently related in that public security or, more correctly, public peace rests on the prohibition of the use of armed force by private citizens. This prohibition and the resulting expectation of a peaceful resolution of conflicts are necessary to create a space in which citizens dare to engage in social exchange, including communication and trade. If all citizens complied with this prohibition, the state and its security agencies would be unnecessary. However, a small minority does not. The state monopoly on the use of violence to enforce public security is the logical consequence. It maintains a ban on private force and at the same time serves to protect citizens against single individuals who disregard this ban.

Commercial and privately contracted security services challenge this practice with serious consequences for domestic security. Foremost, they create new subnational territories of security and insecurity. By protecting paying customers in shopping malls and gated communities, commercial security guards produce private zones of security, while displacing crime to neighbouring public spaces (Atkinson and Blandy, 2005, p. 180). Both contribute to undermining citizens' expectation of non-violence and increase their fear of public areas. As a result in particular wealthy citizens are withdrawing from these spaces and wider social interaction (Monahan, 2006, p. 173). Decreased social contact with citizens from a broad range of cultural and socioeconomic backgrounds in turn facilitates fear of crime. British residents of gated communities have been observed to regard "the surrounding neighbourhoods as crime-prone localities, despite the fact that they had very low crime rates" (Atkinson and Flint, 2004, p. 879). Moreover, commercial security features such as gates, fences and barriers can hinder public security provision in these areas because they restrict police access to private territories (Atkinson and Flint, 2004, p. 882).

In international relations, the state monopoly on the legitimate use of force has aimed to avoid armed conflict between individuals from different territorial communities. Instead citizens' natural right to employ force is deferred to the state in return for protection against extra-territorial aggressors. The international monopoly of the state on the use of armed force has never been as successfully implemented as that within its national borders. However, the ideal of the territorially sovereign state and the prohibition against the 
transnational use of military force by non-state actors has been central in global affairs. It has reached its fullest expression in the Charter of the United Nations (UN) and the international laws of conflict of the twentieth century. According to the UN Charter (1945) states are the "original members" of the international community responsible for peace and security, and the Charter expressly recognizes the territorial sovereignty of its member states and prohibits foreign intervention within their domestic jurisdictions. Other laws supporting the restriction on the private use of violence in international relations have included the Geneva Conventions, which grant national armed forces special status and protection, and the UN and African Union conventions against mercenarism (Doswald-Beck, 2007). The state monopoly on the use of armed force has thus facilitated a decline in the number of interstate wars since the end of the Second World War. It has also delimited extrastate armed conflicts, i.e. conflicts between a state and a non-state group outside its territory, since 1975 (Gleditsch et al., 2002, p. 624).

The rise of a global security industry challenges the international monopoly of the state on the use of armed force in four ways. Firstly, commercial security providers offer alternative protection against external security threats. They particularly supply safeguards against the perceived 'new' threats such as international terrorism and crime. In the marketing of these companies public security measures need to be complemented by private, i.e. commercial, services because the new threats target individuals rather than national borders, thus overstretching state security agencies (Krahmann, 2011). The security industry even actively suggests that state police and national militaries are incapable of dealing effectively with the new types of transnational security threats. Indeed, in some cases states themselves encourage private citizens and businesses to hire commercial security services against these threats (Financial Times, 2005).

Secondly, security firms have become central to permitting international private actors such as multinational corporations, NGOs and international organizations to operate in countries where there is a lack of public security or where state security forces are corrupt. Although this development has been generally viewed in a positive light, it presents another challenge to the state monopoly on violence which requires further consideration (Fuchs, 2007). Rather than relying on local governments or multinational armed forces to resolve security issues, international security companies have developed capabilities and expertise which have allowed mostly Western businesses, charities and organizations to become independent of state security providers. Increasing globalization and the search for scarce natural resources have raised the demand for such services from multinational businesses. One example is the private supply of security for oil and gas extracting corporations in Nigeria. In 2007, there were "between 1,500 and 2,000 private security companies (PSCs) operating in Nigeria, employing in excess of 100,000 people" (Abrahamsen and Williams, 2007). Major international security firms in Nigeria include G4S's Outsourcing Services Ltd., Control Risks and ArmorGroup. Another example is the use of security firms by NGOs. While many NGOs are reluctant to admit to hiring commercial security guards, empirical evidence of the growing reliance of NGOs on contracted security guards is mounting (Spearin, 2001; Spearin, 2008; Cockayne, 2006). The intermeshing of security and development has been one factor that has led NGOs to take more 'proactive' stances towards the provision of aid in conflict regions. Security firms use the moral dilemmas of NGOs to promote their services. As Control Risks (2012c) writes: "Combating the increasing risks faced by aid workers across the globe is a difficult balancing act: too much overt security and aid workers risk being 
associated with armed forces, too little and an organisation's duty of care can be questioned."

Thirdly, global security firms such as the now defunct Executive Outcomes and Sandline International have supplied international help in internal conflicts (Howe, 1998; Aning, 2001; Francis, 1999). In 1995, for instance, the Sierra Leonean government hired Executive Outcomes for $\$ 35$ million to support its poorly trained national armed forces in the conflict with the Revolutionary United Front (Francis, 1999; Cleaver 2000). The company's initial success, however, was short lived. Only five months later, the military of Sierra Leone aligned itself with the revolutionaries and overthrew the government. To regain power the ousted government brought in Sandline International which (in addition to ECOMOG troops) facilitated its return to power in February 1998.

Fourthly, international security companies support state police and armed forces in international interventions. While contractors have always reinforced national militaries in major interstate wars, the post-Cold War era has seen the emergence of military contracting for international peacekeeping and peacemaking missions (CBO, 2008, p. 13). In fact, some companies such as Blackwater have claimed that they would be able to supply peacekeeping troops for an international intervention in Darfur if the international community could agree on hiring them (Washington Times, 2006). As table 3 has indicated, however, so far the largest demand comes from states participating in multinational military operations which are not sustainable in terms of scope and duration without the support of security contractors.

\section{Community}

The commercialization, privatization and deterritorialization of security also affect the value, norm and system of national and international security communities. Specifically, the market in security services contrasts the provision of security from a collective good supplied to a community of citizens living within a national territory with a notion of security as an individual and exclusive property. Whereas the state-centric territorial order led to the predominant conception of security as related to the protection of national borders and everybody living within them, the commercialization of security has gone hand in hand with normative and practical shifts towards individual security. Mostly, this turn from national borders and military security concerns towards the survival of individuals and groups has been perceived as progressive. However, it has also some negative implications (McDonald, 2002; Paris, 2001). In particular, an individualized conception and provision of security threatens the norm of security as a collective good as well as the coherence and perpetuation of existing security communities at the national and international levels.

In domestic affairs, the commercialization of security contributes to the erosion of the norm of a national security community embodied in the territorial nation-state through three major developments. Firstly, the marketization of security leads to the creation of subnational 'security communities' based not on citizenship, but on the ability to pay for commercial security services. Gated communities are the direct illustration of these new types of 'security communities'. Commercially protected corporate spaces, shopping malls and entertainment centres create different kinds of security communities where financial prowess determines membership. Private corporations not only obtain contract security for their assets, but also for their employees. Entry to shopping malls and entertainment parks 
depends upon the ability of citizens to act as consumers within commercially secured 'public' private spaces. What differentiates private security communities from those of the state are the lack of social and political cohesion and the absence of a collective sense of identity and mutual responsibility. Declining notions of community are characteristic of gated communities where residents of high-income communities have a significantly lower sense of community than non-gated housing precincts (Wilson-Doenges, 2000, p. 605). Gated communities are also perceived as a "process of exclusion and distinction" by the residents of neighbouring housing areas (Atkinson and Flint, 2004, p. 883). Security firms exacerbate the division between these private security communities and non-members by being responsible exclusively to their clients (Joh, 2004, p. 90). In short, the commercialization of security contributes to eroding the norms, values and practices that link between territorial citizenship, national community and security, and replaces it with commercial status and transactions.

Secondly, the commercialization of security not only leads to the formation of new 'private' security communities, but also to the individualization of security. One development questioning the concept and practice of security communities is the assertion that security risks are individual rather than collective. Security firms contribute to this development through marketing strategies that emphasize personal and corporate differences with regards to the exposure and vulnerability to particular security threats. According to these marketing strategies contemporary security threats are not collective, but personal, requiring "bespoke Security Service tailored to your individual needs and requirements" which only commercial security contractors can supply (Golden Crown Security, 2012). In fact, the assertion that clients' security needs are distinct is one of the most widely-found statements on security firms' websites (Allander Security, 2012; Britsafe Security, 2012; Danhouse Security, 2012; Elite Protection, 2012). With the conception that security is related to individuals rather than communities comes the responsibilization of consumers with regard to their personal or corporate safety. Security companies present this responsibility often as an issue of personal or corporate governance and duty of care (Octaga Security Services, 2012). According to Control Risks (2012d), "Expecting the unexpected has become a corporate responsibility". Even Western states seem to imply an increased responsibility of citizens and corporations to protect themselves (O'Malley, 2006, p. 49; Mythen and Walklate, 2006, p. 134).

Thirdly, by suggesting that security is best provided at the individual or corporate level, the commercialization of security encourages a declining commitment of citizens to personally participate in or finance collective public security measures. This development has been most extensive in the USA where "issues of secession and tax withdrawal become a problem" due to the rise of gated communities and mass private properties (Webster et al., 2002, p. 317). But also in Europe an emerging disconnect between security and the national territorial community can be observed in trends such as the growing demand for commercial security services and the dissatisfaction with public police despite decreasing crime rates.

In international affairs, the impact of the global security industry on national and international security communities can be noted in two main contexts. One has been the impact of international security firms on national security communities. In terms of social and political cohesion, collective identity and mutual responsibility, the greatest effect of international commercial security provision has been on developing and failed states. In these countries, security firms have allowed multinational corporations, international 
organizations, local businesses and wealthy individuals to obtain their own security independently from the national community, often exacerbating the weakness of public security agencies and community relations. The territoriality of this practice is illustrated by privately secured and fenced corporate enclaves in Africa, gated residential communities in Latin America and the 'green zones' of Iraq and Haiti (Avant, 2005; Henry and Higate, 2009). In these examples, security firms create nearly autonomous areas within the host countries, often alienating the wider population (Ferguson, 2005, p. 378). The visible separation between the commercially protected and those living in neighbouring areas contributes to the formation of different 'security communities' within these national territories. As James Ferguson (2005, p. 379) describes, the "enclaves of mineral-extractive investment on the [African] continent are normally tightly integrated with the head offices of multinational corporations and metropolitan centers, but sharply walled off from their own national societies (often literally walled, with bricks and razor wire)".

Another development facilitated by the availability of commercial security and military services has been the weakening of international security communities. In International Relations Theory, the concept of international security communities refers to a "region of states whose people maintain dependable expectations of peaceful change" (Adler and Barnett, 1998, p. 30). It represents the fullest application of the state-centric political order which rests on the recognition of the territorial sovereignty of all member countries. Nevertheless, there have been few examples where the expectation of peaceful conflict resolution among groups of states has achieved the same prevalence as within national borders. Foremost among them have been NATO and the European Union where the sense of community necessary for the functioning of an international security community has been reinforced by common interpretations of external threats, a high density of social interactions and a collective identity (Adler and Barnett, 1998, p. 38). While the defining feature of international security communities is their internal relations, at a maximum they also view and address external threats as common security concerns. In the North Atlantic Treaty (1949), the ideal of mutual responsibility for protection from external threats is institutionalized in Article 5 which proscribes "that an armed attack against one or more of them in Europe or North America shall be considered an attack against them all". Despite the persistence and even growth of NATO, the past decades have witnessed a weakening sense of community among its members illustrated by diverse threat interpretations and a preference for 'coalitions of the willing' for the implementation of international security policies. The security industry has reinforced these trends through its discourse of individualized security risks and the supply of non-state security forces for international interventions. The former has contributed to a shift in the threat perception of the transatlantic security community away from the common threat of the Warsaw Pact to a multitude of 'new' security concerns such as terrorism, crime, proliferation, immigration and economic instability. Although most of these transnational threats can only be effectively addressed through collective efforts, the impression of many governments that their national territories are exposed to these threats to varying degrees has facilitated different national attitudes and approaches. In addition, the non-existential nature of the 'new' security concerns has implied that contemporary military interventions are 'wars of choice'. The latter has permitted Western governments to act unilaterally when there is no agreement over the need for international military operations by supplementing their forces with military contractors. 
The recent war in Iraq has been the primary example of this trend. Already at the outset there was a significant disagreement among the members of the transatlantic security community regarding the nature and level of the threat from Iraq. Later the USA and the UK led the intervention by a 'coalition of the willing' without a UN mandate. Since major members of the transatlantic community such as France and Germany refused to become engaged in the war, the coalition forces hired about 160,000 security and military contractors to support their mission (CBO, 2008, p. 1; Hansard, 2008, Col. 1552W). The refusal of the US government as occupying state to accept full responsibility for public security after the war, but to leave it to security companies added another twist to the Iraq case. If it becomes a precedent, it suggests a further change to the state-centric territorial order by reliving intervening states of their international role in the provision of public security (Sassoli, 2005, 663). Its effect on the national and international sense of community became apparent in the aftermath as Iraqis increasingly viewed the coalition forces not as liberators, but as hostile powers.

\section{Rule of Law}

A third area affected by the distinct territorialities of commercial security has been the norm, value and practice of the rule of law. Within the state-centric order, territoriality has played a major role in the definition and implementation of the rule of law because it delineates: (1) who has the right to create the law, (2) who is subject to the law, (3) who enforces the law, and (4) to whom the law and its enforcers are accountable. At the centre of these four dimensions has been the norm of territorial sovereignty. It regards the creation and application of modern law within the territorial borders of the state and concerns the formation of international law focused on inter-state relations (Brown cited in Fitzpatrick, 2002 , p. 308). In addition, this order ascribes to the state the right and responsibility for the enforcement of the rule of law within its territory and for the implementation of international law. As with the provision of security, the ideal-typical territorial state holds the monopoly on the legitimate use of force with regards to the implementation of the rule of law. Thus, Fitzpatrick (2002, p. 311-12) writes: "The use of force in law enforcement is one of the exclusive powers of the post-Westphalian state". In international relations, the monopoly on the use of armed force with regards to international law is a major factor in the international provision and maintenance of security. It is expressed through the special status attributed to the state and national armed forces in the UN Charta and the Geneva Conventions and includes "an obligation to prevent territory from becoming a staging area for armed attacks on other states" (Fitzpatrick, 2002, p. 311). In sum, the rule of law goes beyond the mere creation of a rule-governed national and international order (O'Donnell, 2004 , p. 32). Modern rule of law is inherently related to the concepts of community and democracy, requiring the involvement of citizens in the definition of laws, the opportunity for redress, and the public accountability and control of the agencies charged with the implementation of the rule of law (Raz cited in O'Donnell, 2004, p. 35).

The commercialization of security challenges the definition, application, implementation, and democratic accountability and control of the rule of law in multiple ways. At the domestic level, contracted security contributes to the creation of private spaces where separate sets of rules apply in addition to public law. Gated communities have been described as "a form of semiprivate government", where residential associations or developers proscribe how members may behave and who is permitted to enter its 
commercially policed spaces (Kennedy, 1995, p. 763). Notable about these private territories is the limited involvement of residents in the definition of communal regulations. Citizens are "the relatively powerless partner" in a gated community because they often only have the option of deciding whether or not to rent or buy a property which requires of them to sign up to regulations already set by the developers or residential associations (Webster et al., 2002, pp. 317; also Atkinson and Blandy, 2005, p. 177-8). Frequently, these regulations are "incomprehensible and non-negotiable" (Mackenzie cited in Atkinson and Blandy, 2005, p. 183). They can include the "banning as a threat to community order such things as basketball hoops over garages, heavy dogs, cats of any weight, too many poodles or smooching grandparents" (Kennedy, 1995, p. 762-3). The private rules set within these precincts also affect non-members, ranging from restrictions to freedom of speech and movement to racial discrimination (Kennedy, 1995, p. 761). The autonomous rule setting in private territories violates contemporary democratic principles in three areas. Firstly, it disregards the principle of equality because "in many countries the voting rights in condominiums and corporations are distributed according to the value of the property" (Glasze, 2005, p. 228). Secondly, in private residential or semi-public corporate territories, there is no formal opposition or critical media reporting on decisions. Thirdly, in shopping malls, corporate estates or private residences investors often hold the majority of or control over the property, being able to determine the rules and management of these (semi)private spaces in line with their profit-maximizing objectives. Often there are no ways for nonmembers to seek redress within the system of private community association regulations.

In addition, the growing role of security companies in their enforcement presents another challenge to the ideal of territorial sovereignty. Private systems of law "may provide a wide range of discretion to security personnel, resulting in discriminatory enforcement of the associations regulations" (Kennedy, 1995, p. 769). Also the implementation of public law by security firms undermines the monopoly of the state on the legitimate use of violence for the execution of the rule of law. The employees of these firms "behave like public law enforcement officers: detaining individuals, conducting searches, investigating crimes, and maintaining order" (Joh, 2004, p. 50). Little research has been conducted about the abuse of force by the employees of security firms operating in Western democracies (Kirby, 2008, p. $84)$. Joh $(2004$, p. 59,62$)$ suggests that the tendency of commercial security guards to avoid obvious coercive means in their rule or law enforcement stems from their distinct objectives. State police forces are mostly concerned with arrests in order to hold citizens accountable for breaches of the rule of law. Contracted security guards are primarily employed in order to protect their clients from security threats or losses due to theft. As a result, the police operate "largely reactive", while security firms engage in preventative practices (Joh, 2004, p. 59). The greater legal rights of commercial security forces as the agents of the owners of private properties and enclaves facilitate the use of proactive security strategies. Contrary to public police, commercial security guards may bar or eject "those considered undesirable or unwelcome from the malls, corporate campuses, and other private spaces that are policed privately" (Joh, 2004, p. 65). This power to exclude citizens which are, rightly or not, perceived as potential security threats from the benefits of these private territories acts undermines the central notions of the rule of law that everybody is treated equally and considered not guilty until convicted.

Finally, despite the growing contribution of security firms to the enforcement of the rule of law, the firms and the actions of their employees are typically not subject to the same 
standards of legal and constitutional accountability and control as public security forces. National laws requiring the licensing of domestic security companies in Europe and North America are often not more than a decade old (CoESS, 2008; de Waard, 1999). The UK government, for instance, favoured self-regulation for many years and only adopted a law on the security industry in 2001. Also in the USA there are still a number of states which lack licensing regimes for security firms such as Mississippi, Alabama and Colorado. Other US state licensing laws require "little more than asking applicants to promise that they are qualified to be a security guard" (Maahs and Hemmens cited in Joh, 2004, p. 108). Since the requirements for vetting, training and equipment vary considerably, security firms have the option of evading strict standards by registering in the states and countries with the least controls (Stenning, 2000, p. 338). While there has been a tightening of licensing laws in recent years, there are still two major omissions across most Western democracies. One regards the regulation of in-house security personnel, i.e. those who are directly employed by a corporation or shopping mall rather than by a security firm. The other concerns the behaviour of contracted security personnel (Joh, 2004, p. 107). The latter is particularly notable in comparison with the public police who are subject to constitutional or legal controls with regards to the detention, arrest and use of force against citizens (Joh, 2004, p. $60)$. In the case of private territories, the Western rule of law still assumes that the owner is 'king of his castle' and that citizens who enter them have to accept private rules and their private enforcement. That both the rules and the commercial security forces are only accountable to and controlled by the owners disregards the spread of mass private properties as working, shopping and spare time environments in Europe and North America.

The proliferation of transnational military and security firms has similar fundamental consequences for the state-centric territorial conception of the rule of law in international relations. Foremost, the increasingly global make-up and operation of these companies transforms the territorial foundations of the regulation of the use of armed force in international law. As Fitzpatrick (2002, p. 317) argues

\footnotetext{
"The legal definitions of international armed conflict are constructed against the background of the post-Westphalian system. Thus, Common Article 2 of the Geneva Conventions of 1949 envisions international armed conflict between High Contracting Parties. Only territorial states are capable of ratifying the Geneva Conventions. The complex rules that govern international armed conflict .... thus control behaviour among states."
}

The conceptualization, creation and the application of the contemporary international laws of armed conflict are all based on the territorial sovereignty of the state (Dinstein, 2004). They assume that armed conflict primarily occurs between states; proscribe that only states can agree on the definition of the international laws of war; and are mostly applicable to states and their agents. These international laws of armed conflict are complemented by several conventions such as the First Additional Protocol to the Geneva Conventions (1977), the UN Conventions Convention against the Recruitment, Use, Financing and Training of Mercenaries (1989) and the Organization of African Unity Convention for the Elimination of Mercenaries in Africa (1977) which seek to ensure that states remain the only legitimate wielders of collective violence in international relations (Kassebaum, 2000; Zarate, 1998). Arguably, the state-centric territorial conception of the international rule of law has experienced some modification in recent years, including an increasingly homocentric approach as indicated by the terminological shift from the 'laws of armed conflict' to 'international humanitarian law' (Meron, 2006, p. 2). Nevertheless, states remain the 
primary addressee of the international laws of armed conflict. Individuals can only be held directly responsible for a very limited set of grave breaches against international criminal law, such as genocide and crimes against humanity (Weigelt and Märker, 2007, p. 378). Moreover, there has not been a venue outside the territorial jurisdiction of states in which international criminal laws could be enforced until the formation of the International Criminal Court in 2002. In the case of the international laws of armed conflict, it remains until today the obligation of states to prevent or prosecute violations (Weigelt and Märker, 2007, p. 379).

The contemporary global security industry evades and undermines the international rule of law on the use of armed force in two main respects. Firstly, security companies are neither states nor are they always 'accompanying the armed forces', a special category that was introduced in the Geneva Conventions in 1949. As a result large parts of international law are not applicable to these firms, although they often use armed force in local conflicts and to protect their private clients. In Iraq, for instance, it has been reported that the "Employees of security companies... frequently come under fire from insurgents. When they do, they fire back" (Priest and Flaherty, 2004). Imke-Ilse Drews (2007, p. 339) concludes that the Blackwater contractors who defended the CPA headquarters in Najaf in April 2004 could even be tried as mercenaries under the Geneva Conventions because they were fighting in what was then still an 'international conflict' or 'alien occupation'. Many military and security contractors would fit the definition of mercenaries outlined in Article 47 of the First Additional Protocol to the Geneva Conventions and used in the UN and AU conventions against mercenarism. However, the cumulative nature of the definition, the difficulty of proving the profit motivation of a security contractor and the unwillingness of states to enforce these conventions have so far prevented prosecution. Many Western states have instead become complicit in the circumvention of the international laws of conflict by accepting international security companies as legitimate and legal actors (Lehnardt, 2007, p. 140). The US government has officially endorsed the use of "deadly force" by US security contractors "when such force reasonably appears necessary to execute their security mission to protect assets/persons, consistent with the terms and conditions contained in their contract or with their job description" (DoD, 2010). Other states such as the UK have tolerated international security companies which export armed services from their territories.

Secondly, the international operation and organization of international security firms and the diverse nationalities of their employees hinders the enforcement of the international laws of armed conflict. Foremost is the problem of jurisdictional responsibility within an order based on territorial sovereignty. While states are formally responsible for the implementation of international humanitarian law, in practice it is often unclear which state has the right and duty to prosecute security contractors for violations. When security firms work directly for states and their agencies, the responsibility appears to rest with the employing country (Lehnardt, 2007). When security firms are hired by private citizens, businesses or organizations, as is increasingly the case, the question becomes more difficult to answer (Gillard, 2008). Does prosecution fall to the state where the violation took place? Is it the responsibility of the state where the security company employing the perpetrator is registered? Or is it a case for the state where the offender is a national citizen? Western governments have so far shown little willingness or interest to accept their responsibility for the implementation of international law, leaving the problem to countries where 
international security firms are operating. Unfortunately these countries are typically those which lack effective and efficient law enforcement agencies - one reason why global security contractors are working there in the first place. Efforts to address these issues through national and international regulations on the export of commercial security services have been limited. Only the US and South Africa have national licensing regimes for the global operation of international security companies (Caparini, 2008). States have also rejected recent attempts to forge new international laws with regards to international security firms. The Montreux Document (2008) which is supported by 38 countries, including Afghanistan, Angola, Australia, Austria, Canada, China, France, Germany, Iraq, Poland, Sierra Leone, South Africa, Sweden, Switzerland, the UK, Ukraine, and the USA, has instead reinforced existing international laws of armed conflict and human rights laws.

\section{Democracy}

Finally, the rise of the security industry is challenging the norms, values and practices of modern democracy in Europe and North America. Democracy, according to Arthur Benz and Yannis Papadopoulos (2006, p. 5), is "characterized by structures and processes in which collectively binding decisions are made by responsive actors in the interest of those citizens who authorized them to rule in their place. Thus the democratic legitimacy of a polity and of particular policies requires a circular relationship between decision-makers and the citizenry". Territoriality has played two major roles in the definition of Western democracy. Firstly, it has defined the scope of the polity or citizenry. Secondly, it has set the boundaries for the application and implementation of collectively binding decisions (Hettne, 2000, p. 35). Importantly, the territorial correspondence between both areas provides that "[e]very person affected by a collective decision should have the opportunity to express his or her will" (Benz and Papadopoulos, 2006, p. 6).

The commercialization of security at the domestic and international levels has important consequences for democratic security policy making. It affects particularly the definition of security threats and strategies and the accountability of security providers. The first regards a transformation of who is involved in the definition of security threats and strategies, who is the primary object of security and the processes by which decisions concerning the provision of security are taken (Krahmann, 2008; Leander, 2005). The state-centric ideal of democracy envisages the democratic deliberation and public and parliamentary scrutiny of public security policies by elected representatives of the total citizenry based on an examination of potential security threats to the community. By contrast, security companies and their clients decide unilaterally upon which kinds of security services they consider appropriate for the protection of individual customers and their private properties. Even the commercial security supplied to new collectives such as gated residences is characterized by a lack democratic decision-making. Against the notion that housing associations represent a classic form of democratic self-government, stand inequalities in voting rights based on property value and the "dictatorial" practices of investment firms owning entire residences (Glasze, 2005, p. 228). Effectively, "the political organisation in private neighbourhoods is returning to the days of a census suffrage where political influence was institutionally based on status and class" (Glasze, 2005, pp. 228-9).

In addition, commercial security providers are exclusively accountable to their clients. The typical security firm is "only interested in the directions, approval, and guidance of its 
employer" (Joh, 2004, p. 90). However, with the rise of mass private property and the displacement of crime to neighbouring areas, a growing number of citizens not involved in this decision-making process are directly affected by its consequences. As Atkinson and Blandy (2005, p. 179) conclude, "Gated communities express a broader trend of private decision-making that has wider and public ramifications. In short, the locational choices made by affluent households affect outcomes for the poor in terms of city sustainability, security and social segregation." In place of collective and democratic control, security decision-making becomes increasingly fragmented and privatized. Loader (1999, p. 384) goes even further, arguing that

“The security market thus offers - and may appeal as - an 'institutionalized exit from politics' (Bauman 1988: 82), an escape from the 'democratic' requirements that attend the struggle for a share of public policing. In enables individuals, organisations and communities to pursue their particularistic (and self-defined) security requirements without reference to any conception of the common good, and free of the obligations associated with the practice of democratic citizenship."

The emergence of commercially secured mass private properties not only questions the state-centric model of democracy at the domestic level, the global security industry also can contribute to its destabilization at the international level. The effect of international security firms on the democratic provision of security can be observed in three dimensions. Firstly, international security companies can challenge the democratic control of security by national governments through the supply of security services for actors within. Arguably, this is particularly controversial when their clients are large and influential or when their services have a direct impact on the security of non-customers. However, the deficit of democratic control over the commercial provision of security can be observed independently of the question of whether or not this lack has negative consequences for public security. Within the $E U$, for instance, the mutual recognition of national licences of security firms indubitably restricts the ability of national parliaments to control the ways in which contract security guards may operate within their sovereign territories. Similarly, the absence of import and export restrictions on commercial security services in most countries around the world has created an area where private, albeit not always armed, force can be employed beyond the democratic control which characterizes state agencies such as national police and armed forces.

Secondly, international military and security companies can support non-democratic factions in internal conflicts, government-business collusion and coups d'état and hinder democratic development (McIntyre and Weiss, 2007). Executive Outcomes and Sandline International were widely criticized for their linkages with extractive corporations through major holding companies. This included allegations that these companies were reimbursed by the weak and poor governments by whom they had been hired through the granting of licences to foreign oil and mining corporations (Fuchs, 2007). Also the failure of security companies to instil democratic values into national armed forces which they had been training in military operations and strategy has been noted in cases such as Executive Outcomes in Sierra Leone and MPRI in Croatia (Avant, 2005, pp. 100-113; Singer, 2003, pp. 113-4, 126-7). Finally, leading mercenaries such as the infamous Simon Mann, one of the founders of Sandline International, have been involved in the coups d'état attempt in Equatorial Guinea in 2004. Although the target in this case was not a democratic government, the interests of the private investors who backed Mann were clearly not the promotion of democracy, but rather the exploitation of the country's oil resources. 
Thirdly, global security firms can further weaken the democratic accountability of international interventions. One aspect is the use of security contractors by international organizations and NGOs such as UNHCR, UNDP, WFP, UNICEP and ICRC in humanitarian missions (Ebo, 2008, p. 146). The private protection supplied by security firms has increasingly allowed non-state actors to operate in conflict regions where these actors have previously depended on security support from national or multinational armed forces (Spearin, 2001; Spearin, 2008). Moreover, some companies such as Blackwater have proposed that international security firms could complement or even substitute for national militaries in international peacekeeping and peacemaking operations (Robertson, 2008). The proponents of this approach argue that it can help make international interventions independent of the vagaries of the democratic decision-making process which has led to the "shameful withdrawal of Western nations from peacekeeping activities in conflicts of limited national interest" (Brooks and Chorey, 2008, p. 117). Another aspect concerns the circumvention of public and parliamentary approval for the deployment of national armed forces in military interventions abroad (Wulf, 2008, pp. 199-200). The availability of military and security contractors to bolster their armed forces has been one factor which has allowed the UK and the US governments to ignore public opposition to the war in Iraq despite one of the "biggest anti-war demonstration ever held in Britain and worldwide" (MacAskill and White, 2003). More importantly, the hiring of military and security companies can undermine the democratic control of governments through the requirement of parliamentary consent for the deployment of soldiers abroad. The 155,000 contractors employed by the US armed forces allowed the Bush administration to more than double the personnel for its military operation in Iraq without having to ask Congress for the approval of additional troops (Avant, 2000, pp. 1-2; Avant and Sigelman, 2010). The lack of public and parliamentary information about the numbers and functions of contractors hired by Western militaries in international interventions exacerbates the problem of democratic control. Only the USA has so far attempted to address this problem through the creation of a database in 2006, while the UK government was still in the process of setting up a similar file in 2008 (GAO, 2006, pp. 14-20; GAO, 2007, p. 11).

\section{Conclusion}

The proliferation of security and military companies not only contributes to a diffusion of functions and powers from national governments to international and non-state actors, but also has profound implications for the territorial foundations of the norms, values and practices that have shaped Western security governance during the past century. Many other factors also contribute to the transformation of the "golden age" nation-state, the international state-centric order and its underlying values. On the ideological side has been the rise of Neoliberalism with its promotion of new forms of public service provision and public accountability. On the practical side have been the perceived demands of the postCold War security environment, technological changes and globalization. This chapter has sought to illustrate that military and security companies have not merely been beneficiaries of these changes. They have contributed to and reinforced them through their own discourses and practices.

This chapter has identified four areas which the diffusion of power to military and security companies suggests the rise of alternative norms, values and forms of security governance in Europe and North America. The first regards a transformation of the norm of the state 
monopoly on violence illustrated by the increasing functions and acceptance of security contractors. The second is the diffusion of security governance from national to private 'security communities' and from collective to individual values. The third includes the ways in which security contractors challenge state-centric forms of law which regulate the use of armed force nationally and internationally and the emergence of security industry selfregulation. The fourth includes a public disillusionment with the normative ideal of democracy and a turn towards individualized and marketized forms of decision-making. Arguably these alternatives have not replaced the norms, values and practices of security governance centred on territorial states. Instead, they have created a system where state and non-state forms of security governance exist in parallel or even in hybrid systems, each creating their own rationalities and concerns.

\section{Bibliography}

Abrahamsen, Rita, and Michael C. Williams (2007) The Globalization of Private Security - Country Report: Nigeria, Report, University of Aberystwyth, at: http://users.aber.ac.uk/rbh/privatesecurity/country\%20report-nigeria.pdf.

Adler, Emmanuel, and Michael Barnett (1998) 'A Framework for the Study of Security Communities', in: ibid. (eds.) Security Communities (Cambridge: Cambridge University Press).

Aegis (2011) United Nations Global Compact - Communications in Progress (London: Aegis, March), http://www.aegisworld.com/uploads/UNGC\%20COP\%200411.pdf, date accessed 9 January 2012.

Allander Security (2012) Home, http://www.allandersecurity.com/securitysolutions.html, date accessed 9 January 2012.

Andreas, Peter, and Richard Price (2001) 'From War Fighting to Crime Fighting: Transforming the American National Security State', International Studies Review, 3 (3), 31-52.

Aning, E. K. (2001) 'Whither Africa's Security in the New Millennium: State- or Mercenary-induced Stability?' Global Society, 15 (2), 149-171.

Atkinson, Rowland, and John Flint (2004) 'Fortress UK? Gated Communities, the Spatial Revolt of the Elites and Time-Space Trajectories of Segregation', Housing Studies, 19 (6), 875-892.

Atkinson, Rowland, and Sarah Blandy (2005) 'Introduction: International Perspectives on The New Enclavism and the Rise of Gated Communities', Housing Studies, 20 (2), 177-186.

Avant, Deborah D. (2000) 'Privatizing Military Training', Foreign Policy in Focus, 5 (17), 1-2.

Avant, Deborah D. (2005) The Market for Force: The Consequences of Privatizing Security (Cambridge: Cambridge University Press).

Avant, Deborah D., and Lee Sigelman (2010) 'Private Security and Democracy: Lessons from the US in Iraq', Security Studies, 19 (2), 230-265.

Benz, Arthur, and Yannis Papadopoulos (2006) 'Introduction - Governance and Democracy; Concepts and Key Issues', in: ibid. (eds.) Governance and Democracy: Comparing National, European and International Experiences (London: Routledge), pp. 1-26.

Bislev, Sven (2004) 'Globalization, State Transformation, and Public Security', International Political Science Review, 25 (3), 281-296.

Blackwell, Christopher W. (2003) Athenian Democracy: A Brief Overview, http://www.stoa.org/projects/demos/article_democracy_overview?page=3\&greekEncoding=Unicod eC, date accessed 9 January 2012. 
Blakely, E. J., and M. G. Snyder (1997) Fortress America (Washington, D.C.: Brookings Institution).

Britsafe Security (2012) Training, http://www.britsafe.com/Security/training.asp, date accessed 9 January 2012.

CACl (2012) About Us, http://www.caci.com/about/profile.shtml, date accessed 9 January 2012.

United Nations (1945) Charter of the United Nations, http://www.un.org/en/documents/charter/, date accessed 9 January 2012.

Cockayne, James, (2006) Commercial Security in Humanitarian and Post-conflict Settings: An Exploratory Study (New York: International Peace Academy).

CoESS (2008) Private Security in Europe - CoESS Facts and Figures 2008, http://www.coess.eu/?CategorylD=203, date accessed 9 January 2012.

Community Associations Institute

http://www.caionline.org/info/research/Pages/default.aspx, date accessed 9 March 2009.

(2009),

Congressional Budget Office (CBO), Contractor's Support of U.S. Operations in Iraq (Washington, D.C., August 2008).

Control Risks (2012a) About US, http://www.control-risks.com/aboutUs/SitePages/Home.aspx, date accessed 9 January 2012.

Control Risks (2012b) What We Do - Business Intelligence \& Investigation, http://controlrisks.de/default.aspx?page=316, date accessed 9 January 2012.

Control Risks (2012c) NGOs, http://www.controlrisksgroup.co.uk/default.aspx?page=334, date accessed 9 January 2012.

Control Risks (2012d) What We Do - Managing a Crisis, http://controlrisks.de/default.aspx?page=307, date accessed 9 January 2012.

CSC (2012) About US, http://www.csc.com/about_us/ds/29505-company_profile, date accessed 9 January 2012.

Danhouse Security (2012) Home, http://www.danhouse.co.uk/home.htm, date accessed 9 January 2012.

de Waard, Jaap (1999) 'The Private Security Industry in International Perspective', European Journal on Criminal Policy and Research, 7, 143-174.

Department of Defense (DoD) (2010), Defense Acquisitions Regulations System (DFARS), 252.2257040 http://farsite.hill.af.mil/reghtml/regs/far2afmcfars/fardfars/dfars/dfars252_220.htm, date accessed 6 January 2012.

Dinstein, Yoran (2004) The Conduct of Hostilities under the Law of International Armed Conflict (Cambridge: Cambridge University Press).

Doswald-Beck, Louise (2007) 'Private Military Companies under International Humanitarian Law', in: Simon Chesterman and Chia Lehnardt (eds.) From Mercenaries to Market: The Rise and Regulation of Private Military Companies (Oxford: Oxford University Press), pp. 115-138.

Drews, Imke-Ilse (2007) 'Private Military Companies: The New Mercenaries? - An International Law Analysis', in: Thomas Jäger and Gerhard Kümmel (eds.) Private Military and Security Companies. Changes, Problems, Pitfalls and Prospects (Wiesbaden: VS Verlag), pp. 331-344.

Ebo, Adedeji (2008) 'Private Actors and the Governance of Security in West Africa', in: Andrew Alexandra, Deane-Peter Baker, Marina and Caparini (eds.) Private Military and Security Companies: Ethics, Politics and Civil-military Relations (London: Routledge), pp. 143-158. 
Edgerton, David (2006) Warfare State: Britain, 1920-1970 (Cambridge: Cambridge University Press).

Elite Protection (2012) Home, http://www.eliteprotectionltd.co.uk/, date accessed 9 January 2012.

Ferguson, James (2005) 'Seeing Like an Oil Company: Space, Security, and Global Capital in Neoliberal Africa', American Anthropologist, 107 (3), 377-382.

Financial Times (2005) 'London Businesses Told to Upgrade Security', 14 July.

Fitzpatrick, Joan (2002) 'Sovereignty, Territoriality, and the Rule of Law', Hastings International and Comparative Law Review, 25 (3), 303-340.

Francis, David J. (1999) 'Mercenary Intervention in Sierra Leone: Providing National Security or International Exploitation?' Third World Quarterly, 20 (2), 319-338.

Fuchs, Alice E. (2007) 'Searching for Resources, Offering Security... Private Military Companies in Sierra Leone', in: Thomas Jäger and Gerhard Kümmel (eds.) (2006) Private Military and Security Companies: Chances, Problems, Pitfalls and Prospects (Wiesbaden: VS Verlag für Sozialwissenschaften), pp. 105-120.

G4S (2012) Where We Operate, http://www.g4s.com/uk-security/, date accessed 9 January 2012.

Gerry Cleaver (2000) 'Subcontracting Military Power: The Privatisation of Security in Contemporary Sub-Saharan Africa', Crime Law and Social Change, 33 (1-2), 131-149.

Gillard, Emanuela-Chiara (2008) 'Private Military/Security Companies: The Status of Their Staff and Their Obligations under International Humanitarian Law and the Responsibilities of States in Relation to Their Operations', in: Andrew Alexandra, Deane-peter Baker and Marina Caparini (eds.) Private Military and Security Companies: Ethics, Policies and Civil-Military Relations (London: Routledge), pp. 159-170.

Glasze, Georg (2005) 'Some Reflections on the Economic and Political Organisation of Private Neighbourhoods', Housing Studies, 20 (2), 221-233.

Gleditsch, Nils Petter, Peter Wallensteen, Mikael Eriksson, Margareta Sollenberg and Håvard Strand (2002) 'Armed Conflict 1946-2001: A New Dataset', Journal of Peace Research, 39 (5), 615-637.

Golden Crown Security (2012) Protecting Your Premises, http://www.goldencrownsecurity.com/, date accessed 9 January 2012.

Government Accountability Office (GAO) (2006), Military Operations: High-Level DOD Action Needed to Address Long-standing Problems with Management and Oversight of Contractors Supporting Deployed Operations, GAO-07-145 (Washington, D.C., December).

GAO (2007) Stabilizing and Rebuilding Iraq: Conditions in Iraq Are Conductive to Fraud, Waste and Abuse, GAO-07-525T (Washington, D.C., 23 April).

Guardsmark (2011) 'World-Renowned Security Publication Warns of Rising Threats from Unexpected Sources', Press Release, $15 \quad$ September, http://www.guardsmark.com/press/press_sec.asp?nav=5\&subnav=1\&content_id=123, date accessed 9 January 2012.

Hansard (House of Commons), 'Iraq: Peacekeeping Operations', Written Answers, Vol. 483, Session 2007-8, 26 November 2008, Column 1552W.

Henry, Marsha, and Paul Higate (2009) Insecure Spaces: Peacekeeping in Liberia, Kosovo and Haiti (London: Zed).

Hettne, Björn (2000) 'The Fate of Citizenship in Post-Westphalia', Citizenship Studies, 4 (1), 35-46.

Hogan, Michael J. (2000) A Cross of Iron: Harry S. Truman and the Origins of the National Security State (Cambridge: Cambridge University Press). 
Howe, Herbert M. (1998) 'Private Security Forces and African Stability: The Case of Executive Outcomes', Journal of Modern African Studies, 36 (2), 307-331.

Joh, Elizabeth (2004) 'The Paradox of Private Policing', The Journal of Criminal Law and Criminology, 95 (1), 49-132.

Kassebaum, David (2000) 'A Question of Facts: The Legal Use of Private Security Firms in Bosnia', Columbia Journal of Transnational Law, 38 (3), 581-602.

Kennedy, David J. (1995) 'Residential Associations as State Actors: Regulating the Impact of Gated Communities on Nonmembers', The Yale Law Journal, 105 (3), 761-793.

Kingsnorth, Paul, (2008) 'Cities for Sale', Guardian, 29 March.

Kirby, Andrew (2008) 'The Production of Private Space and Its Implications for Urban Social Relations', Political Geography, 27 (1), 74-95.

Krahmann, Elke (2008) 'Security: Collective Good or Commodity?' European Journal of International Relations, 14 (3), 379-404.

Krahmann, Elke (2010) States, Citizens and the Privatization of Security (Cambridge: Cambridge University Press).

Krahmann, Elke (2011) 'Beck and Beyond: Selling Security in the World Risk Society,' Review of International Studies, 37 (1), 349-372.

Krahmann, Elke (2012) 'From 'Mercenaries' to 'Private Security Contractors': The (Re)construction of Armed Security Providers in International Legal Discourses', Millennium: Journal of International Studies, 40 (2), 339 - 359.

Krasner, Stephen D. (1995/6) 'Compromising Westphalia', International Security, 20 (3), 115-151.

L-3 Communications (2011) L-3 Announces First Quarter 2011 Results, http://www.l3com.com/press-releases/l-3-announces-first-quarter-2011-results.html, date accessed 9 January 2012.

Leander, Anna (2005) 'The Power to Construct International Security: On the Significance of Private Military Companies', Millennium: Journal of International Studies, 33(3), 803-26.

Leander, Anna (2006) Eroding State Authority? Private Military Companies and the Legitimate Use of Force (Rome: Centro Militare di Studi Strategici).

Lehnardt, Chia (2007) 'Private Military Companies and State Responsibility', in: Simon Chesterman and Chia Lehnardt (eds.) From Mercenaries to Market: The Rise and Regulation of Private Military Companies (Oxford: Oxford University Press), pp. 139-157.

Leibfried, Stefan, Kerstin Martens, Peter Mayer and Achim Hurrelmann (eds.) (2008) Transforming the Golden-Age Nation State (London: Palgrave).

Loader, Ian (1999) 'Consumer Culture and the Commodification of Policing and Security', Sociology, $33(2), 373-392$.

Loader, lan, and Neil Walker (2001) 'Policing as a Public Good: Reconstituting the Connections between Policing and the State', Theoretical Criminology, 5 (1), 9-35.

MacAskill, Ewen, and Michael White (2003), 'Blair to Defy Anti-War Protests', Guardian, 17 February.

McDonald, Matt (2002) 'Human Security and the Construction of Security', Global Society, 16 (3), 277-295.

McIntyre, Angela, and Taya Weiss (2007) 'Weak Governments in Search of Strength: Africa's Experience of Mercenaries and Private Military Companies', in: Simon Chesterman and Chia Lehnardt 
(eds.) From Mercenaries to Market: The Rise and Regulation of Private Military Companies (Oxford: Oxford University Press), pp. 67-81.

Meron, Theodor (2006) The Humanization of International Law (Leiden: Martinus Nijhoff).

Monahan, Torin (2006) 'Electronic Fortification in Phoenix: Surveillance Technologies and Social Regulation in Residential Communities', Urban Affairs Review, 42 (2), 169-192.

Montreux Document on Private Military and Security Companies (2008), http://www.eda.admin.ch/psc, date accessed 9 January 2012.

Mythen, Gabe, and Sandra Walklate, (2006) 'Communicating the Terrorist Risk: Harnessing a Culture of Fear?' Crime, Media, Culture, 2 (2), 123-142.

NATO (1949), North Atlantic Treaty, http://www.nato.int/cps/en/natolive/official_texts_17120.htm, date accessed 9 January 2012.

O'Donnell, Guillermo (2004) 'Why the Rule of Law Matters', Journal of Democracy, 15 (4), 32-46.

O'Malley, Pat (2006) 'Criminology and Risk', in Sandra Waltlake and Gabe Mythen (eds.) Beyond the Risk Society (Buckingham: Open University Press), pp. 43-59.

Octaga Security Services (2012) Training, http://www.octaga.co.uk/training/, date accessed 9 January 2012.

Olive Group (2012) About Olive - PDF Fact Sheet, http://www.olivegroup.com/about.htm, date accessed 9 January 2012.

Paris, Roland (2001) 'Human Security: Paradigm Shift or Hot Air?' International Security, 26 (2), 87102.

Percy, Sarah (2007) Mercenaries: The History of a Norm in International Relations (Oxford: Oxford University Press).

Priest, Dana, and Mary P. Flaherty (2004) 'Slain Contractors Were in Iraq Working Security Detail', Washington Post, 2 April.

Robertson, David (2008) 'Blackwater: US Security Firm in Iraq Shooting Claim Looks for Peace Work', Times, 19 March.

Sassoli, Marco (2005) 'Legislation and Maintenance of Public Order and Civil Life by Occupying Powers', The European Journal of International Law, 16 (4), 661-694.

Securitas (2012) About Securitas, http://www.securitas.com/en/, date accessed 9 January 2012.

Shearing, Clifford D., and Philipp C. Stenning (1983) 'Private Security: Implications for Social Control', Social Problems, 30 (5), 493-506.

Singer, Peter W. (2003) Corporate Warriors: The Rise of the Privatized Military Industry (Ithaca, NY: Cornell).

Spearin, Christopher (2001) 'Private Security Companies and Humanitarians: A Corporate Solution to Securing Humanitarian Spaces', International Peacekeeping, 8 (1), 20-43.

Spearin, Christopher (2008) 'Private, Armed and Humanitarian? States, NGOs, International Private Security Companies and Shifting Humanitarianism', Security Dialogue, 39 (4), 363-382.

Stenning, Philip C. (2000) 'Powers and Accountability of Private Police', European Journal on Criminal Policy and Research, 8 (3), 325-352.

The Risk Advisory Group (2012) About Us, http://www.riskadvisory.net/about-us, date accessed 9 January 2012. 
Thomson, Janice E. (1994) Mercenaries, Pirates and Sovereigns (Princeton: Princeton University Press).

United States Bureau of Labor Statistics (2008) Occupational Outlook Handbook 2008-09, http://www.bls.gov/oco/ocos160.htm, date accessed 10 April 2009.

US Census Bureau (2008) American Housing Survey for the United States 2007 (Washington, D.C.: US Government Printing Office).

Washington Times (2006) 'Private Firms Eye Darfur', 2 October.

Weber, Max (1994) Political Writings (Cambridge: Cambridge University Press).

Webster, Chris, Georg Glasze and Klaus Frantz (2002) 'The Global Spread of Gated Communities', Environment and Planning B: Planning and Design, 29 (3), 315-320.

Weigelt, Katja, and Frank Märker (2007) 'Who Is Responsible? The Use of PMCs in Armed Conflict and International Law', in: Thomas Jäger and Gerhard Kümmel (eds.) Private Military and Security Companies. Chances, Problems, Pitfalls and Prospects (Wiesbaden: Verlag für Sozialwissenschaften), 377-393.

Wilson-Doenges, Georjeanna (2000) 'An Exploration of Sense of Community and Fear of Crime in Gated Communities', Environment and Behavior, 32 (5), 597-611.

Wulf, Herbert (2008) 'Privatization of Security, International Interventions and the Democratic Control of Armed Forces', in: Andrew Alexandra, Deane-Peter Baker, Marina and Caparini (eds.) Private Military and Security Companies: Ethics, Politics and Civil-military Relations (London: Routledge), pp. 199-200.

Zacher, Mark W. (2001) 'The Territorial Integrity Norm: International Boundaries and the Use of Force', International Organization, 55 (2), 215-250.

Zarate, Juan Carlos (1998) 'The Emergence of a New Dog of War: Private International Security Companies, International Law and the New World Disorder', Stanford Journal of International Law, 34 (1), 75-162. 